\title{
BIOMASS ENERGY POTENTIAL FROM AGRICULTURAL RESIDUES IN ERITREA
}

\author{
Gürkan Alp Kağan GÜRDİL1*, Mahtem MENGSTU1', Tesfit MEDHN² \\ ${ }^{1}$ Ondokuz Mayis University, Faculty of Agriculture, Department of Agricultural Machinery Technologies and Engineering, 55200, \\ Samsun, Turkey \\ ${ }^{2}$ Eritrea Institute of Technology, College of Engineering, Department of Agricultural Engineering, Mainefhi, Eritrea
}

\begin{abstract}
This study aimed to estimate the amount of biomass energy that can be acquired from crop residues in Eritrea, a country in the horn of Africa with a population of 6 million and having a national income per capita is around 150 US dollars. It's an agricultural country. The energy potential of crop residues was calculated by considering the calorific values and the amount of available residue. For the year 2015, the total calorific value of agricultural residues was estimated approximately $1332.34 \mathrm{TJ}$. According to the amount of agricultural residues, the most contributing crops were sorghum (50\%) and millet (27\%). Thus, it can be inferred that knowing the particular and general biomass energy potential of agricultural residues could help in managing energy sources and planning projects.
\end{abstract}

Keywords: Biomass, Agricultural residue, Energy, Eritrea

${ }^{*}$ Corresponding author: Ondokuz Mayis University, Faculty of Agriculture, Department of Agricultural Machinery Technologies and Engineering. 55200, Samsun, Turkey

E mail: ggurdil@omu.edu.tr (G.A.K. GÜRDİL)

$\begin{array}{lll}\text { Gürkan Alp Kağan GÜRDILL } & \text { (iD) https://orcid.org/0000-0001-7764-3977 Received: May 22, 2021 }\end{array}$

Mahtem MENGSTU (iD) https://orcid.org/0000-0001-5768-9150 Accepted: June 10, 2021

$\begin{array}{lll}\text { Tesfit MEDHN } & \text { (iD) https://orcid.org/0000-0002-4005-1780 Published: July 01, 2021 }\end{array}$

Cite as: Gürdil GAK, Mengstu M, Medhn T. 2021. Biomass energy potential from agricultural residues in Eritrea. BSJ Agri, 4(3): 103-106.

\section{Introduction}

Energy supply, specifically the issue of alternative energy sources, has seized the thoughts of people worldwide and has stimulated more research, dispute and action: personal, political and commercial; perhaps as equal as any other environmental issue in the course of time (Onochie et al., 2015). The ever-rising energy demand is directly related to the increase in the standard of living and the advancement of new technologies (Demirel et al., 2014). Considering renewable energy sources such as biomass energy has been one of the principal solutions to the depletion of fossil fuels.

The use of biomass energy dates back to the dawn of history. Followed by food crops, grassy and woody plants, residues from agriculture or forestry, oil-rich algae, and the organic component of municipal and industrial wastes, wood has been the largest source of biomass energy. Every organic matter existing in the biosphere is regarded as biomass. It constitutes of plant and animal origin including the materials obtained as a result of their natural and artificial transformation (Perea-Moreno et al., 2019). Biomass exists in diversified forms such as wood, sawdust, straw, seed waste, manure, paper waste, household waste, and wastewater (Long et al., 2013). By virtue of their nature, some biomass energy sources are used directly as fuel. However, others should be subjected to certain treatments, requiring various technologies before they are used. Converting into a range of valuable biofuels, chemicals, and other products, the application of biomass energy has the potential to significantly minimize the emission of greenhouse gases, reliance on fossil fuels, and eventually support agricultural industries (Mohtasham, 2015). Due to its local abundance and low price biomass appears to be encouraging renewable energy resource. As the main bioenergy resource, it can be produced from natural materials, such as harvest residues, energy crops, algae, and agricultural wastes (Mirkouei et al., 2017). Sustainable bioenergy sources have the capacity to promote economic opportunities, energy security, and environmental benefits (Yang et al., 2017). Bioenergy has been suggested as a sustainable source of energy that has a higher potential to displace the dominant fossil-based energy (Mirkouei et al., 2017).

Employing alternative energy sources is a key factor in improving the livelihood of needy societies and make economic sustainability achievable (Kaygusuz, 2011). Production of charcoal is one common domestic practice of meeting the requirement of energy. When used as fuel this has the potential of reducing indoor air pollution. Furthermore, it has a direct impact on economic growth because people can market the extra charcoal (Zulu and Richardson, 2013).

In Eritrea, like in most developing countries, a major proportion of energy is contributed by biomass sources. A report from the Department of Energy shows that out of the total energy supply $66.3 \%$ was derived from local biomass fuels (Semere, 2001). With the growth of the 


\section{Black Sea Journal of Agriculture}

population in rural areas, it is obvious that the reliance on biomass energy sources will continue. Consequently, the demand for these sources will also keep on increasing (Zemenfes, 2001). Therefore, exploring and evaluating a country's potential energy sources is highly significant so as the standard of living is improved by providing a sufficient source of energy to society. Thus this study aimed to estimate the amount of biomass energy that can be acquired from crop residues in Eritrea.

\section{Material and Methods}

In the assessment of biomass resources two ways namely resources focused and demand-based approaches are used (Van den and Vis, 2014). From the aforesaid methods, the resource-based approach is the most customary approach used worldwide for the calculation of biomass and bio-energy potential. In this method, specific biomass types like agricultural residue, forest residue, and their byproducts are put into consideration (Long et al., 2013). Thus, this study follows the resourcebased approach to evaluate the biomass energy potential in Eritrea.

Despite the fact that crop residues have different categories (gross residue sand surplus residues), in this study, only the surplus residues are considered since the farmers use the others for different purposes. Data from the annual report of the Ministry of Agriculture (MOA) of Eritrea for the year 2015 were used to compute the amount of residue from the seasonal year production of main crops cultivated in Eritrea. The formula used for calculating the bio-energy potential from crop residues is adopted from (Hiloidhari and Baruah, 2011; TerraponPfaff et al., 2012). The total residue has to be determined first as the remaining residue depends on it (equation 1).

$\mathrm{AAR}=\mathrm{AAP} * \mathrm{RPR}^{*} \mathrm{~A}$

Where (AAR) is the available amount of agricultural residues of the crop in tons, (AAP) the amount of agricultural product in tons, (RPR) residue-to-product ratio, and (A) the availability of residues relevant for developing countries (Elias and Shabbir, 2018). The RPR values are obtained from different published research works conducted in developing countries in the SubSaharan region of Africa as it is represented in Table 1.

Table 1. Parameters and their values used in estimation

\begin{tabular}{lccccc}
\hline FC & R & RPR & A (\%) & LHV(M)kg-1) & Reference \\
\hline Sorghum & Straw & 1.75 & 60 & 12.38 & (Kimutai et al., 2014) \\
Maize & Cob & 0.3 & 100 & 15.5 & (Singh et al., 2008) \\
Millet & Straw & 1.75 & 60 & 18.16 & (Friedl et al., 2005) \\
Barley & Stalks & 2.7 & 60 & 18.6 & (Friedl et al., 2005) \\
Wheat & Straw & 0.8 & 15 & 17.15 & (Singh et al., 2008) \\
Hanfez & Straw & 1.75 & 60 & 17.88 & (Friedl et al., 2005) \\
Sesame & Straw & 0.5 & 56 & 14.35 & (Zabaniotou et al., 2008) \\
Groundnut & Shells & 0.48 & 40 & 15.56 & (Jekayinfa and Scholz, 2009) \\
\hline FC= field crops, R= residue type, RPR= residue to product ratio, A= availability & & &
\end{tabular}

$\overline{\mathrm{FC}}=$ field crops, $\mathrm{R}=$ residue type, $\mathrm{RPR}=$ residue to product ratio, $\mathrm{A}=$ availability, $\mathrm{LHV}=$ lower heating value.

The portion of available residues from crop production after other parts are used for different purposes is known as the surplus availability (Hiloidhari and Baruah, 2011). Finally, the bio-energy crop residue potential is estimated from equation (equation 2) as follows;

$\mathrm{THV}=\mathrm{AAR} * \mathrm{LHV}$

Where (THV) the total heating value of agricultural residues of the crop in TJ, (AAR) is the available amount of agricultural residues of the crop in tons, and (LHV) lower heating value of air dry residues of the crop in MJ.kg-1.

\section{Results and Discussion}

Using the resource focused approach the total amount of agricultural residues of major crops Barley, Groundnut, Wheat, Hanfez (combination of wheat and barley), Sorghum, Millet, Sesame, and Maize was estimated to be 85265.28 tons in Eritrea (Table 2).
As it has been represented in Fig 1, out of the total residue sorghum and millet comprise about $50 \%$ and $27 \%$ respectively being the major ones.

Table 2. Amount of agricultural product and available residues in tones of selected field crops in Eritrea

\begin{tabular}{cccc}
\hline FC & R & AAP & AAR \\
\hline Sorghum & Straw & 32091 & 33695.6 \\
Maize & Cob & 34019 & 10205.7 \\
Millet & Straw & 17412 & 18282.6 \\
Barley & Stalks & 12209 & 19778.6 \\
Wheat & Straw & 8495 & 1019.4 \\
Hanfez & Stalks & 2923 & 1918.2 \\
Sesame & Straw & 1061 & 297.1 \\
Groundnut & Shells & 355 & 68.2 \\
TOTAL & & & 85265.28
\end{tabular}

$\mathrm{FC}=$ field crops, $\mathrm{R}=$ residue type, $\mathrm{AAP}=$ amount of agricultural residues, $\mathrm{AAR}=$ amount of agricultural product. 
In calculating the total amount of heating value, although the total amount of crop residues is estimated to be 85265.28tons, it should be noted that since residues are used for various purposes the surplus availability factor was considered to estimate the reliable amount of energy. Hence, as shown in Table 3, the total heating value of residues for the year 2015 was estimated to be 1332.34TJ

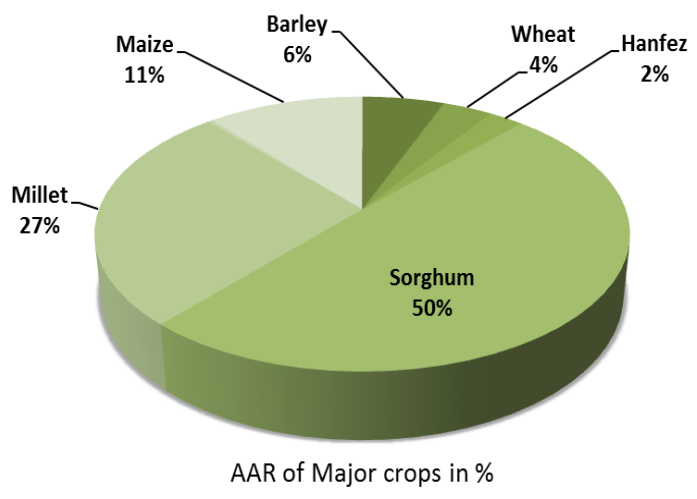

Figure 1. Amount of available residue (AAR) of major field crops.

Table 3. Total heating values of agricultural residues in Eritrea

\begin{tabular}{lcc}
\hline FC & R & THV (T) $)$ \\
\hline Sorghum & Straw & 417.15 \\
Maize & Cob & 158.19 \\
Millet & Straw & 332.01 \\
Barley & Stalks & 367.88 \\
Wheat & Straw & 17.48 \\
Hanfez & Stalks & 34.30 \\
Groundnut & Shells & 4.26 \\
Sesame & Straw & 1.06 \\
TOTAL & & 1332.34 \\
\hline FC $=$ field crops, R= residue type THV=total heating value
\end{tabular}

\section{Conclusion}

The study was done to estimate the biomass energy potential in Eritrea. Like many other countries, Eritrea's source of energy depends on the import of fossil fuels. The subject of energy demand remains to be a solutionseeking challenge. Energy scarcity and energy-related cases are problems that need to be addressed at the soonest possible. In facilitating the possible solutions knowing the capacity and potential of every alternative source of energy is crucial. Thus, knowing the biomass energy potential could help in managing energy sources, planning projects, and policymaking as a whole. The total heating value of crops in Eritrea was found to be 1332.34TJ. It is easy to infer that this considerable amount of energy is significantly contributing to the energy demand of the country. Additionally, establishing systems to change this potential into other kinds of energy sources such as biogas would definitely pay off.

\section{Author Contributions}

All authors contributed equally to this work. All authors reviewed and approved the manuscript.

\section{Conflict of Interest}

The authors declare that there is no conflict of interest.

\section{References}

Demirel B, Gürdil GAK. 2014. Evaluation of waste/residues produced as a result of agricultural activities as solid biofuel. In: Proceedings of the Energy Agriculture and Biofuels 4th National Workshop Proceedings, 28-29 May, Samsun, Turkey, 229-238.

Elias WG, Shabbir HG. 2018. Potential of bio-energy production in Ethiopia based on available biomass residues. Biomass and Bioenergy. 111: 77-87.

Friedl A, Padouvas E, Rotter H, Varmuza K. 2005. Prediction of heating values of biomass fuel from elemental composition. Anal Chim Acta, 544: 191-198.

Hiloidhari M, Baruah DC. 2011. Crop residue biomass for decentralized electrical power generation in rural areas (part 1): investigation of spatial availability. Renew Sustain Energy Rev, 15: 1885-1892.

Jekayinfa SO, Scholz V. 2009. Potential availability of energetically usable crop residues in Nigeria Energy Sources, Part A: Recovery. Util Environ Effects, 31: 687-697.

Kaygusuz K. 2011. Energy services and energy poverty for sustainable rural development, Renew. Sustain. Energy Rev, 15: 936-947.

Kimutai SK, Muumbo AM, Siagi ZO, Kiprop AK. 2014. A study on agricultural residues as a substitute to fire wood in Kenya: A Review on Major Crops. Energy Technol Policy, 4: 2224-3232.

Long H, Li X, Wang H, Jia J. 2013. Biomass resources and their bioenergy potential estimation: a review. Renew Sustain Energy Rev, 26: 344-352.

Mirkouei A, Haapala K. R, Sessions J, Murthy G. S. 2017. A mixed biomass-based energy supply chain for enhancing economic and environmental sustainability benefits: A multi-criteria decision making framework. Applied Energy. vol 206: issue C, 1088-1101

Mohtasham J. 2015. Review Article-Renewable Energies. Energy Procedia, 74: 1289-1297.

Onochie UP, Aliu SA., Itabor N., Damisah LE, Eyakwanor TO. 2015. A Review on the use of biomass energy for electricity generation: Environmental impact on climate. Int J Eng Sci Res Tech, 4(9): 674-681.

Perea-Moreno A, Samerón-Manzano E, Perea-Moreno J. 2019. Biomass as renewable energy: Worldwide research trends. Sustainability, 11: 863

Semere H. 2001. Current energy uses and technologies in rural Eritrea. In: Proceedings of the National Policy Seminar on Energy for Rural Development in Eritrea, 2-3 November, Asmara, Eritrea, 257-258.

Singh J, Panesar BS, Sharma SK. 2008. Energy potential through crop biomass using geographical information system - a cases study of Punjab. Biomass Bioenergy, 32: 301-307.

Terrapon-Pfaff JC, Fischedick M, Monheim H. 2012. Energy potentials and sustainability- the case of sisal residues in Tanzania. Energy Sustain Dev, 16: 312-319.

Van den D, Vis M.W. 2014. Harmonization of biomass resource assessments, best practices and methods handbook. Biomass Energy Europe, BTG Biomass Technology Group B.V, 


\section{Black Sea Journal of Agriculture}

Enschede, Netherlands, 1th ed., pp 1.

Yang Y, Brammer JG, Wright DG, Scott JA, Serrano C, Bridgwater AV. 2017. Combined heat and power from the intermediate pyrolysis of biomass materials: performance, economics and environmental impact. Applied Energy, 191: 639-652.

Zabaniotou A, Ioannidou O, Antonakou E, Lappas A. 2008. Experimental study of Pyrolysis for potential energy, hydrogen and carbon material production from lignocellulosic biomass. Int J Hydrogen Energy, 33: 2433-
2444.

Zemenfes, T. 2001. Energy and rural development. In: Proceedings of the National Policy Seminar on Energy for Rural Development in Eritrea, 2-3 November, Asmara, Eritrea, 278-281.

Zulu C, Richardson B. 2013. Charcoal, livelihoods and poverty reduction: evidence from sub-Saharan Africa. Energy Sustain Dev, 17: 127-137. 